\title{
EVALUASI SISTEM INFORMASI KENDARAAN (GF SERVICE) DI BINUS UNIVERSITY BERDASARKAN KERANGKA COBIT PADA DOMAIN DELIVERY AND SUPPORT
}

\author{
Tangkas Udiono $^{1}$; Haris Setia Budi ${ }^{2}$; Mariyani ${ }^{3}$ \\ ${ }^{1,2,3}$ Computerized Accounting Department, School of Information Systems, BINUS University \\ Jln. K.H. Syahdan No. 9, Palmerah, Jakarta Barat 11480 \\ 1tangkas@binus.edu
}

\begin{abstract}
Information Systems Audit is an activity that is carried out in a company that aims to ensure compliance with existing policies. General Services is one of the units in BINUS University whose activities in the form of services such as Transportation and Document Courier, Copy Centre and General Facility. However, this study is limited to the Transportation and Document Courier unit that uses an online reservation application gfservice.binus.ac.id. Maturity level of the existing information systems in Directorate General Services specifically Transportation and Document Courier based on COBIT Maturity Model is 2,951 (Repeatable but Intuitive) or approaching from the standards set by the International is 3:00, which means the process has been documented and communicated well. This study also conducted an evaluation of the quality of information systems and quality of information available. The result is positive impact on users' satisfaction, that means the increases of information quality and the quality of information systems of GF Services would increase student and employee satisfaction, but it also explained the factors that affect success utilization of existing information systems in order to rise to the level to 4, which means managed and Measurable. The results of the regression analysis and correlation between the quality factors of information systems and the quality of information on student satisfaction and employee are $38.2 \%$ and $48.1 \%$; while the rest is influenced by other factors not addressed in this study.
\end{abstract}

Keywords: evaluation, information systems audit, COBIT

\begin{abstract}
ABSTRAK
Audit Sistem Informasi adalah kegiatan yang dilakukan dalam suatu perusahaan yang bertujuan untuk menjamin dipatuhinya kebijakan-kebijakan yang ada. General Services merupakan salah satu unit yang ada di BINUS University yang kegiatannya dalam bentuk pelayanan berupa Transportation and Document Courier, Copy Centre and General Facility. Penelitian ini dibatasi hanya pada unit Transportation and Document Courier yang menggunakan Aplikasi reservasi online yaitu gfservice.binus.ac.id. Tingkat kematangan sistem informasi yang ada di Direktorat General Services khususnya Transportation and Document Courier berdasarkan Maturity Model dari COBIT adalah 2.951 (Repeatable but Intuitive) atau mendekati dari standar yang ditetapkan secara International yaitu 3.00. Artinya, proses telah didokumentasikan dan dikomunikasikan dengan baik. Dalam penelitian ini evaluasi juga dilakukan terhadap kualitas sistem informasi dan kualitas informasi yang ada dengan hasil ada pengaruh positif terhadap kepuasan penggunanya. Artinya, meningkatnya kualitas informasi dan kualitas sistem informasi GF Services akan meningkatkan kepuasan mahasiswa dan karyawan. Selain itu, dijelaskan pula faktor-faktor yang memengaruhi keberhasilan pemanfaatan sistem informasi yang ada agar dapat naik ke tingkat 4 yang berarti managed and measureable. Hasil analisis regresi dan korelasi antara faktor kualitas sistem informasi dan kualitas informasi terhadap kepuasan mahasiswa dan karyawan sebesar 38.2\% dan 48.1\%. Sementara selebihnya dipengaruhi oleh faktor-faktor lain tidak dibahas dalam penelitian ini.
\end{abstract}

Kata kunci: evaluasi, audit sistem informasi, COBIT 


\section{PENDAHULUAN}

Audit Sistem Informasi adalah kegiatan yang terstruktur dalam mengevaluasi komponenkomponen yang ada untuk menentukan bahwa sebuah sistem informasi yang digunakan oleh organisasi dapat dikatakan baik. Selain itu, audit sistem informasi juga ingin menjamin dipatuhinya kebijakan-kebijakan yang ada dalam organisasi. Kebutuhan audit sistem informasi berawal dari kesadaran bahwa komputer berpengaruh dalam kegiatan di dalam suatu organisasi (Gondodiyoto, 2007), sehingga perlu adanya pengendalian seperti halnya sumber daya penting lainnya dalam organisasi.

General Services merupakan salah satu unit yang membawahi bentuk pelayanan berupa Transportation and Document Courier, Copy Centre, and General Facility. Penelitian ini dibatasi hanya pada unit Transportation and Document Courier. Transportation and Document Courier dipimpin oleh seorang Section Head seperti digambarkan dalam diagram berikut.

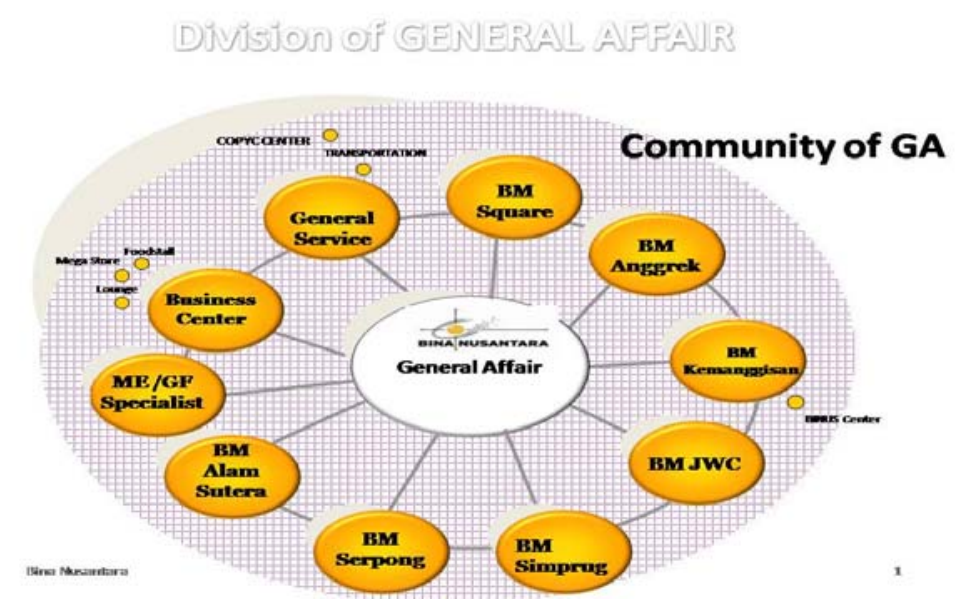

Gambar 1 Diagram General Affair

Jumlah kendaraan yang berada di bawah naungan Transportation and Document Courier adalah sebanyak 34 unit yang mencakup pelayanan untuk 7 lokasi, seperti terdapat dalam Tabel 1.

Tabel 1 Alokasi Jumlah Kendaraan

\begin{tabular}{cc}
\hline Lokasi & Jumlah Kendaraan \\
\hline Kemanggisan dan Kebun Jeruk & 17 \\
Senayan & 2 \\
Simprug & 3 \\
Serpong & 4 \\
Tanjung Duren & 4 \\
Kemanggisan 1 & 2 \\
Alam Sutera & 2 \\
\hline
\end{tabular}


Adapun prosedur yang berjalan selama ini untuk melakukan pemesanan kendaraan adalah seperti tercantum dalam diagram berikut.

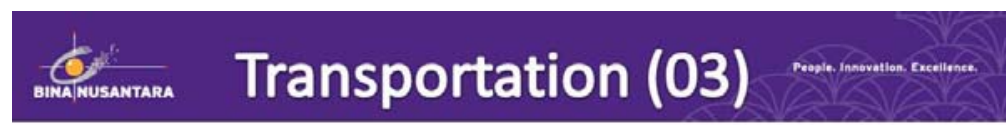

\section{Reservation Procedur}

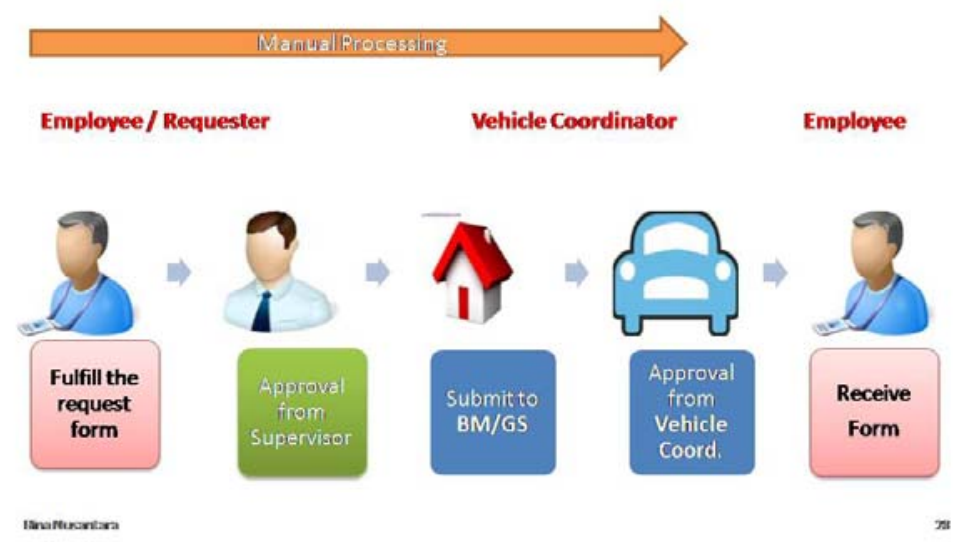

Gambar 2 Gambaran Prosedur Peminjaman Kendaraan

Sedangkan untuk pengiriman dokumen adalah dokumen yang ditujukan untuk sesama karyawan perusahaan, dengan kebijakan: document only, financial (official purpose), distribution on campuss network, central receiving location $\rightarrow$ All-BM office/Finance Office (Anggrek)/GA Office (Syahdan), provide the sender and receiver information.

Berdasarkan uraian, maka masalah pokok yang akan diteliti sebagai berikut. Pertama, bagaimanakah tingkat kematangan sistem informasi yang ada di Direktorat General Services khususnya Transportation and Document Courier berdasarkan Maturity Model dari COBIT. Kedua, bagaimana tanggapan pengguna sistem informasi GF Services terhadap kualitas informasi yang disajikan. Ketiga, bagaimana hubungan antara tingkat kematangan sistem informasi yang ada dan kulitas informasi yang dihasilkan terhadap kepuasan pengguna. Keempat, apa saja faktor yang memengaruhi keberhasilan pemanfaatan sistem informasi yang ada. Evaluasi sistem informasi $G F$ Services - Transportation and Document Courier ini bertujuan untuk mengetahui tingkat kematangan sistem informasi yang ada. Dengan mengetahui tingkat kematangan sistem informasi yang ada, maka pengelola dapat dengan pasti melakukan tindakan tindakan perbaikan untuk meningkatkan kualitas layanan sistem informasi tersebut.

\section{METODE}

Rancangan penelitian yang digunakan dalam menyelesaikan makalah ini dimulai dengan studi literatur. Metodologi yang digunakan dalam penelitian ini adalah meliputi beberapa tahapan seperti terlihat pada Gambar 3. 


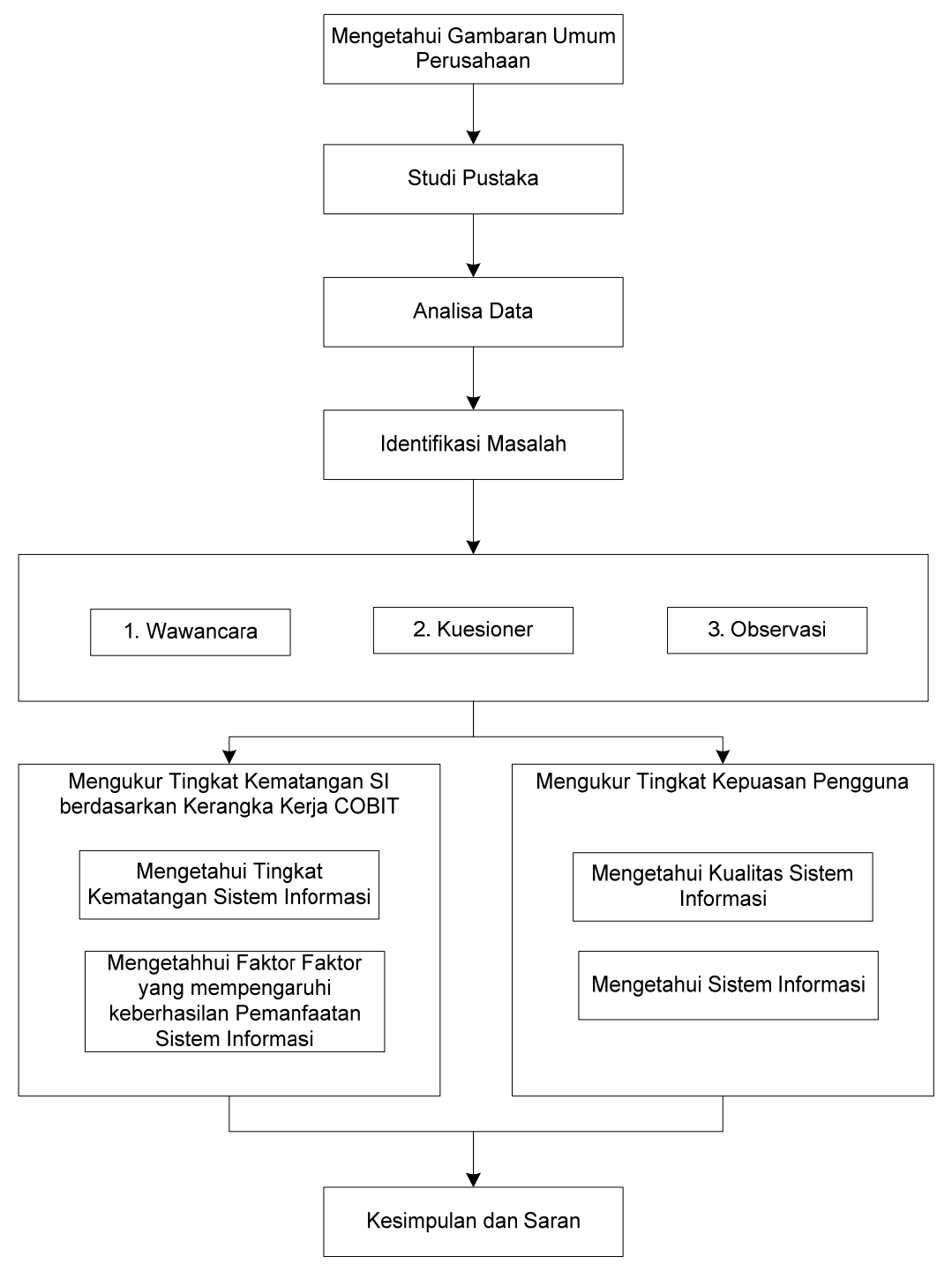

Gambar 3 Metodologi Penelitian

Objek analisis yang akan dilakukan adalah GF Services - Transportation and Document Courier berlokasi di J1. Kebon KH. Syahdan No. 9, Jakarta Barat. Responden sebagai subjek analisis adalah para user baik mahasiwa maupun dosen yang dipilih berdasarkan sampel, dengan menyebarkan kuesioner untuk mendapatkan data kualitas informasi yang akan dianalisis. Kuesioner untuk mendapatkan kualitas informasi yang akan disebarkan mengadopsi penelitian Xiao dan Dasgupta (2002). Kemudian untuk dapat mengukur tingkat kematangan sistem informasi menggunakan alat diagnosis COBIT (Tuttle \& Vandervelde, 2007) untuk mengevaluasi sistem informasi pada GF Services - Transportation and Document Courier. Silitonga dan Ali (2010) serta Fitrianah dan Sucahyo (2010) menyimpulkan bahwa kerangka kerja COBIT adalah yang paling lengkap. Meskipun demikian, karena cakupan COBIT cukup luas, pengamatan dibatasi dengan berfokus pada domain deliver and support seperti yang pernah dilakukan pada penelitian sebelumnya (Hudiarto \& Gautama, 2010).

Control Objective Domain COBIT adalah plan and organize; acquire and implementation; deliver and support; dan monitoring and evaluation (ITGI, 2007). Menurut Abu-Musa (2009), Control Objectives for Information and related Technology (COBIT, saat ini edisi ke-4) adalah sekumpulan dokumentasi best practices untuk IT governance yang dapat membantu auditor, manajemen and 
pengguna (user) untuk menjembatani gap antara risiko bisnis, kebutuhan kontrol, dan permasalahanpermasalahan teknis.

Selanjutnya langkah-langkah yang dilakukan dalam penelitian ini adalah sebagai berikut. Pertama, pengumpulan data yang dibutuhkan baik teknis maupun nonteknis yang terkait dengan Sistem Informasi di GF Services - Transportation and Document Courier. Kedua, wawancara dengan pihak terkait baik dari pimpinan unit maupun pengguna sistem itu sendiri. Ketiga, melakukan evaluasi terhadap Sistem informasi GF Services - Transportation and Document Courier. Melakukan evaluasi terhadap kualitas informasi yang dihasilkan SRSC, yaitu dengan cara menetapkan sampel (Lubis \& Arma, 2003). Menurut Nurhayati (2008):

$$
n=N /\left(N e^{2}+1\right)
$$

di mana

$$
\begin{aligned}
& \mathrm{n}=\text { ukuran sampel; } \\
& \mathrm{N}=\text { Ukuran Populasi; } \\
& \mathrm{e}=\text { persen kelonggaran } .
\end{aligned}
$$

Dengan 24.120 orang mahasiswa dan dosen aktif, jumlah sampelnya menjadi 474 orang. Pertama, mengukur variabel. Menurut Triyanto dan Santosa (2009), pengukuran variabel pertanyaan dapat menggunakan skala Likert yang menunjukan $1=$ sangat tidak setuju sampai $5=$ sangat setuju. Kedua, mengukur validitas dan reliabilitas yang bertujuan untuk menguji butir butir pertanyaan yang ada dalam sebuah angket. Ketiga, melakukan uji regresi untuk mengetahui bagaimana hubungan antara tingkat kematangan sistem informasi dan kualitas informasi yang dihasilkan dengan kepuasan pengguna. Gambar 4 menunjukkan model pengukuran variable dalam penelitian ini.

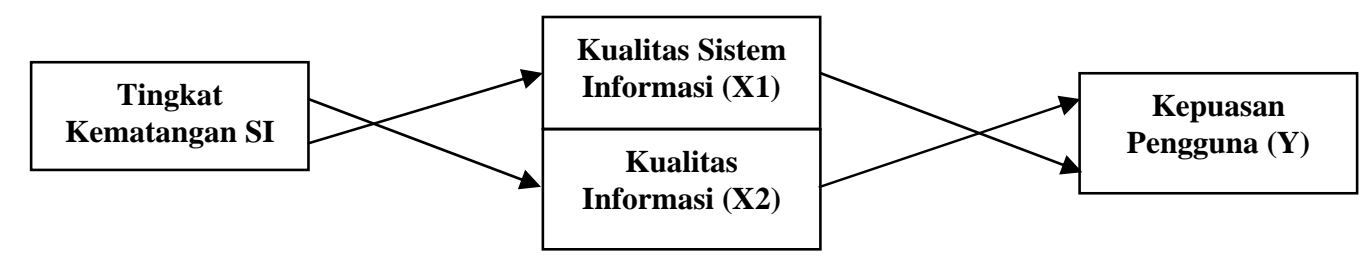

Gambar 4 Gambar Model Pengukuran Variabel Penelitian

Sedangkan menurut Ilias dan Suki (2008) untuk mengukur tingkat keberhasilan sistem informasi adalah sebagai berikut. Pertama, "satisfaction" has a degree of face validity. It is hard to deny the success of a sistem, which its users say that they like. Kedua, the development of the Bailey and Pearson instruments (as a base instrument) and its derivatives has provided a reliable tool for measuring satisfaction and for making satisfaction among studies. Ketiga, reason for the appeal of satisfaction as a success measure is that most of the other measures are so poor; they are either conceptually weak or empirically difficult to obtain.

Evaluasi sistem informasi GF Services - Transportation and Document Courier ini diharapkan dapat mengetahui tingkat kematangan sistem informasi yang ada. Dengan mengetahui tingkat kematangan sistem informasi yang ada, maka pengelola dapat dengan pasti melakukan tindakan tindakan perbaikan untuk meningkatkan kualitas layanan sistem informasi tersebut. 


\section{HASIL DAN PEMBAHASAN}

\section{Hasil Analisis Pengukuran Tingkat Kematangan}

\section{Hasil Analisis Key Goal Indicator (KGI) dan Key Performance Indicator (KPI)}

Berdasarkan paparan tentang best practise didapatkan Jenis layanan yang diberikan oleh GF Services adalah Informasi pemakaian kendaraan; permohonan peminjaman kendaraan penumopang, box maupun bis; permohonan peminjaman kendaraan taxi; dan permohonan pengiriman dokumen. Setiap individu telah memiliki tugas dan wewenangnya masing masing yangperformanya diukur melalui Key Performance indicator (KPI). KPI staf merupakan bagian dari KPI atasan langsung dan begitu seterusnya. Kemudian, pelaksanaan pelaporan dilakukan secara bertahap dan berkelanjutan. Setiap staf diwajibkan untuk menyampaikan laporan setiap minggunya (Weekly Report) yang ditujukan kepada Manajer, selanjutnya setiap bulan Manajer diwajibkan untuk memberikan laporan bulannya (Monthly Report) begitu pula dalam setahun diwajibkan untuk memberikan laporan kegiatannya per 3 bulan atau yang biasa disebut (Quarty Report) kepada Direktur General Fasilities and Service. Secara umum unjuk kerja pelaporan tingkat pelayanan ini sudah dilaksanakan dan berjalan dengan baik.

\section{Hasil Analisis Data dan Pembahasan Maturity Level}

Berdasarkan hasil perhitungan pada masing-masing proses yang ada pada Domain Deliver and Support, dapat diketahui tingkat rata-rata maturity level pada Domain tersebut yang telah dicapai GF Services untuk pengelolaan teknologi informasi seperti tersaji pada Tabel 2. Hasil nilai maturity level didapatkan repeatable but initiative, yang artinya proses prosedur yang ada telah dikembangkan sedemikian rupa sehingga juga diikuti oleh orang lain yang melakukan pekerjaan yang sama. Meskipun demikian, belum ada pelatihan formal atau prosedur standar komunikasi yang dipakai dan juga pertanggungjawaban masih bersifat individual. Pada level ini, terdapat ketergantungan terhadap keahlian individual sehingga kemungkinan terjadinya kesalahan masih bisa terjadi. Sedangkan untuk proses, hasil perhitungan untuk tahap ini memperoleh nilai maturity level berada pada posisi define process. Artinya, prosedur kerja telah distandardisasi dan didokumentasikan serta dikomunikasikan melalui proses-proses pelatihan. Telah dimandatkan pula, bahwa prosedur ini wajib dipatuhi, namun bagaimanapun juga ada deviasi prosedur dalam pelaksanaannya yang belum diakomodasi. Prosedur itu sendiri masih belum memuaskan.

Secara keseluruhan setelah dilakukan rata-rata, maka posisi maturity level berada pada nilai 2.951. Secara standar posisi ini bisa dikatakan baik karena masih berada pada posisi di atas rata rata posisi IT industri pada umumnya (ITGI, 2007). Dengan mengetahui posisi maturity level, maka manajemen saat ini sudah dapat mengetahui target arah peningkatan perbaikan dari kondisi yang ada saat ini. Selanjutnya dilakukan penetapan target Manajer GF Services selaku penanggung jawab dari kegiatan operasional pengelola kendaraan dengan mempertimbangkan kapasitas sumber daya yang dimiliki. Pihak manajemen GF Services mengarahkan pada pencapaian target di posisi 4 atau pada posisi Managed and Measureable.

Tabel 2 menjelaskan mengenai perbandingan perolehan maturity level saat ini dengan target yang ditetapkan oleh pihak manajemen. Sedangkan Gambar 5 menggambarkan posisi pengelolaan unit teknologi informasi yang ada pada GF Services (Abu-Musa, 2009). 
Tabel 2 Perbandingan Maturity Level pada Domain Deliver and Support antara Kondisi Saat Ini dan Target yang Ingin Dicapai

\begin{tabular}{clcc}
\hline \multirow{2}{*}{ No. } & \multicolumn{1}{c}{ Deliver and Support } & \multicolumn{2}{c}{ Maturity Level } \\
\cline { 3 - 4 } & & Sekarang & Target \\
\hline DS 1 & Mendefinisikan dan Mengelola Tingkatan-tingkatan & 2.813 & 4.000 \\
DS 2 & Melayanan & 2.913 & 4.000 \\
DS 3 & Mengelola Layanan-layanan terhadap Pihak Ketiga & 3.087 & 4.000 \\
DS 4 & Memastikan Adanya Pelayanan yang Berkesinambungan & 2.763 & 4.000 \\
DS 5 & Memastikan Keamanan Sistem & 3.024 & 4.000 \\
DS 6 & Mengidentifikasi dan Mengalokasikan Biaya & 2.928 & 4.000 \\
DS 7 & Mendidik dan Melatih Para Pengguna & 2.864 & 4.000 \\
DS 8 & Mengelola Meja Layanan dan Masalah & 2.844 & 4.000 \\
DS 9 & Mengelola Konfigurasi & 2.984 & 4.000 \\
DS 10 & Mengelola Masalah-masalah & 3.033 & 4.000 \\
DS 11 & Mengelola Data & 2.931 & 4.000 \\
DS 12 & Mengelola Lingkungan Fisik & 3.156 & 4.000 \\
DS 13 & Mengelola Operasional & 3.019 & 4.000 \\
\hline \multicolumn{5}{r}{} & Rata-rata & $\mathbf{2 . 9 5 1}$ & $\mathbf{4 . 0 0 0}$ \\
\hline
\end{tabular}

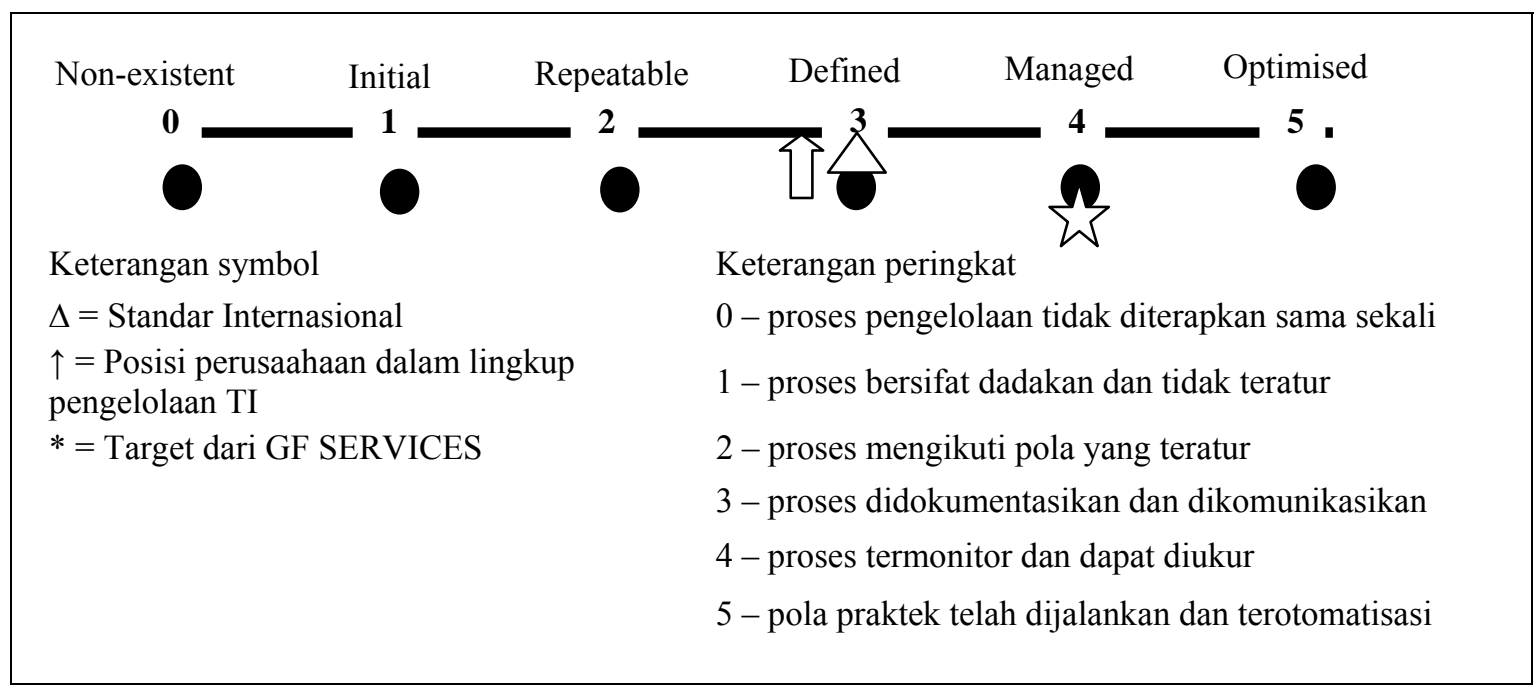

Gambar 5 Perbandingan Kondisi Maturity Level pada Pengelolaan Unit Teknologi Informasi di GF SERVICES

Setelah penetapan target, terlihat adanya selisih posisi yang harus dicapai sebesar 1.049. Untuk menyelesaikan selisih ini, upaya-upaya perbaikan dilakukan pada aktivitas atau proses-proses yang berada pada tahapan-tahpan DS (Deliver \& Suport) yang memiliki nilai kecil atau di bawah standar dan melakukan peningkatan terhadap aktivitas-aktivitas yang lainnya seperti upaya perbaikan, mempertahankan, dan peningkatan aktivitas. Hal tersebut dapat dilakukan dengan cara sebagai berikut. Pertama, mendefinisikan dan mengelola pelayanan. GF Services terbukti mampu memenuhi target yang telah ditentukan. Pengawasan terhadap kegiatan pelayanan ini dilakukan secara terus menerus dan terukur. Kedua, pemberian pelatihan secara berkesinambungan, rutin, dan teratur kepada setiap karyawan agar tercipta pemahaman informasi yang seragam dengan apa yang dilakukan perusahaan. Ketiga, melakukan pengecekan sistem secara lebih ketat terkait perangkat keras dan perangkat lunak, guna meminimalkan gangguan-gangguan teknis. Keempat, lebih meningkatkan pemanfaatan statistik 
pada laporan kinerja sistem, sehingga dapat memberikan gambaran yang jelas tentang kinerja dan kapasitas yang tidak memadai. Kelima, mengelola service desk untuk lebih banyak mengatasi insiden yang muncul sehingga dapat meningkatkan kepuasan kepada pelanggan. Keenam, pemanfaatan knowledge based diharapkan mampu untuk meningkatkan kecepatan pemecahan suatu masalah yang timbul. Ketujuh, divisi TI hendaknya memberikan perhatian lebih dalam pembangunan Knowledge Based System untuk memperlancar operasional kegitan sehari-hari. Kedelapan, tingkat downime perlu dilakukan pembenahan walaupun frekuensi kejadiannya tidak tinggi karena disebabkan oleh terputusnya sumber tenaga/aliran listrik namun tetap perlu ada perbaikan.

Kondisi lingkungan fisik yang ada saat ini sudah cukup baik. Prosedur-prosedur tanggap/darurat bencana sudah disiapkan oleh pengelola gedung. Bila terjadi gangguan seperti bencana alam atau kebakaran, aktivitas terkait teknologi informasi masih bisa dilakukan. Hanya saja terlihat bahwa bahan-bahan yang mudah mengotori atau cenderung bisa membahayakan peralatan listrik seperti makanan ringan, minuman, dispenser, dll posisinya berada dekat peralatan listrik. Hal ini sangat berbahaya jika terjadi hubungan singkat arus listrik.

Kapasitas utama dari GF Services adalah penyediaan layanan yang memadai bagi para pelanggannya baik mahasiswa dan karyawan maupun karyawan. Hal ini ditunjukkan dengan minimnya waktu akibat kegagalan dari sistem (malfunction). Hal ini disebabkan terhentinya aliran listrik atau sumber daya tenaga yang berasal dari PLN. Meskipun demikian kegiatan pemeliharaan untuk sumber daya yang lainnya seperti manusia tetap menjadi perhatian, seperti melakukan pelatihan untuk topik pengembangan, pemeliharaan, dan back up. Akan tetapi, pemberian pelatihan ini yang dilakukan pada saat karyawan masuk dan secara rutin 6 bulan sekali seharusnya bisa lebih ditingkatkan.

Salah satu indikator usaha membangun rencara TI yang berkesinambungan yang mendukung rencana bisnis adalah dengan terpenuhinya permintaan pelayanan yang masuk. Berdasarkan data yang didapat, tercatat $100 \%$ permintaan pelayanan terselesaikan. Ke depannya, pengembangan peralatan IT baik Software (SW) maupun Hardware (HW) ditujukan untuk mempertahankan/meningkatkan kinerja layanan yang diberikan. Pembatasan hak akses untuk tiap-tiap penggunanya bertujuan untuk menjamin integritas dan keamanan aset TI melalui prosedur standar yang ada. Sistem keamanan GF Services bisa dikatakan sangat baik karena tidak ada catatan mengenai kejadian orang lain yang coba memasuki sistem yang ada (hacking).

Untuk meningkatkan efektivitas layanan dan penggunaan TI, semua karyawan baru mendapatkan pelatihan terlebih dahulu. Selain itu, penyegaran setiap bulannya terus dilakukan melalui kegiatan evaluasi yang rutin diadakan. Meskipun demikian, pembuatan buku panduan user dirasakan akan lebih memberikan manfaat, terutama kepada karyawan karyawan baru/karyawan yang berstatus replacement (pengganti).

Kegiatan pengelolaan operasi peminjaman kendaraan merupakan hal yang sangat penting untuk dilakukan karena terkait dengan seluruh sumber daya TI. Kegiatan ini meliputi pendefinisian kebijakan dan prosedur, perencanaan, penjadwalan, pelaksanaan, pengawasan, perlindungan terhadap asset dan pemeliharaan perangkat keras serta menjaga keamanan kondisi lingkungan fisiknya. Jika layanan operasional terhambat, aktivitas bisnis lainnya juga akan menjadi terganggu.

\section{Hasil Analisis Pengukuran Uji Kepuasan Mahasiswa dan Karyawan}

Kuesioner disebar guna mendapatkan data. Penyebaran dilakukan kepada pengguna sistem informasi GF Services, yaitu mahasiswa dan karyawan dan karyawan di lingkungan kampus Universitas Bina Nusantara. Karena jumlah responden sangat sedikit (hanya 100 orang), dalam penyebaran kuesioner ini tidak ditetapkan sampel seperti pada rumus Slovin tetapi seluruh responden akan diberikan kuesioner. Selanjutnya sebelum melakukan analisis data dari responden dilakukan pengujian terlebih dahulu terhadap kuesioner yang akan disebarkan berupa uji validitas dan reabilitas. 


\section{Hasil Uji Validitas}

Kriteria penilaian skor instrumen dalam melakukan uji validitas adalah dengan mendapatkan $r$ table yang terlebih dulu mencari $\mathrm{T}$ table dengan dibantu oleh perangkat statistic SPSS V16.0. Adapun hasil uji validitas adalah bahwa setiap nilai pada butir pertanyaan dikatakan valid jika nilai $r$-hitung yang merupakan nilai dari corrected item total correlation $>r$ table (Nugroho, 2005). Sedangkan nilai reliabilitasnya adalah di atas 0.891 yang artinya reliable. Suatu konstruk dikatakan reliable apabila nilai Cornbach's Alpha minimum adalah 0.6 (Nugroho, 2005).

Kemudian untuk pertanyaan Kualitas Informasi didapatkan hasil uji validitasnya adalah setiap nilai pada butir pertanyaan dikatakan valid jika nilai $r$-hitung yang merupakan nilai dari corrected item total correlation $>r$ table (Nugroho, 2005). Sedangkan nilai reliabilitasnya dari ouput SPSS menunjukan tabel Reliability Statistic pada SPSS yang terlihat pada Cronbach's Alpha $0.801(>0.6)$. Artinya, pertanyaan tersebut berkategori reliable karena nilai Cornbach's Alpha minimum $>0.6$ (Nugroho, 2005).

Selanjutnya adalah mengenai hasil uji validitas dan reliabilitas untuk pertanyaan yang berkaitan dengan kepuasan pelanggan didapatkan hasil data butir pertanyaan valid karena nilai $r$ hitung yang merupakan nilai dari corrected item total correlation $>r$ table (Nugroho, 2005). Sedangkan nilai reliabilitas dari ouput SPSS menunjukan tabel Reliability Statistic pada SPSS yang terlihat pada Cronbach's Alpha 0.904 (>0.6). Artinya, pertanyaan tersebut berkategori reliable karena $>0.6$ (Nugroho, 2005).

\section{Pengaruh Kualitas Sistem Informasi (DeLone \& McLean, 2003) dan Kualitas Informasi terhadap Kepuasan Pelanggan}

Struktur yang akan ditampilkan adalah yang berpengaruh terhadap Kepuasan Mahasiswa dan karyawan (Y) dari variabel Kualitas Sistem Informasi (X1) dan Kualitas Informasi (X2) seperti Gambar 6.
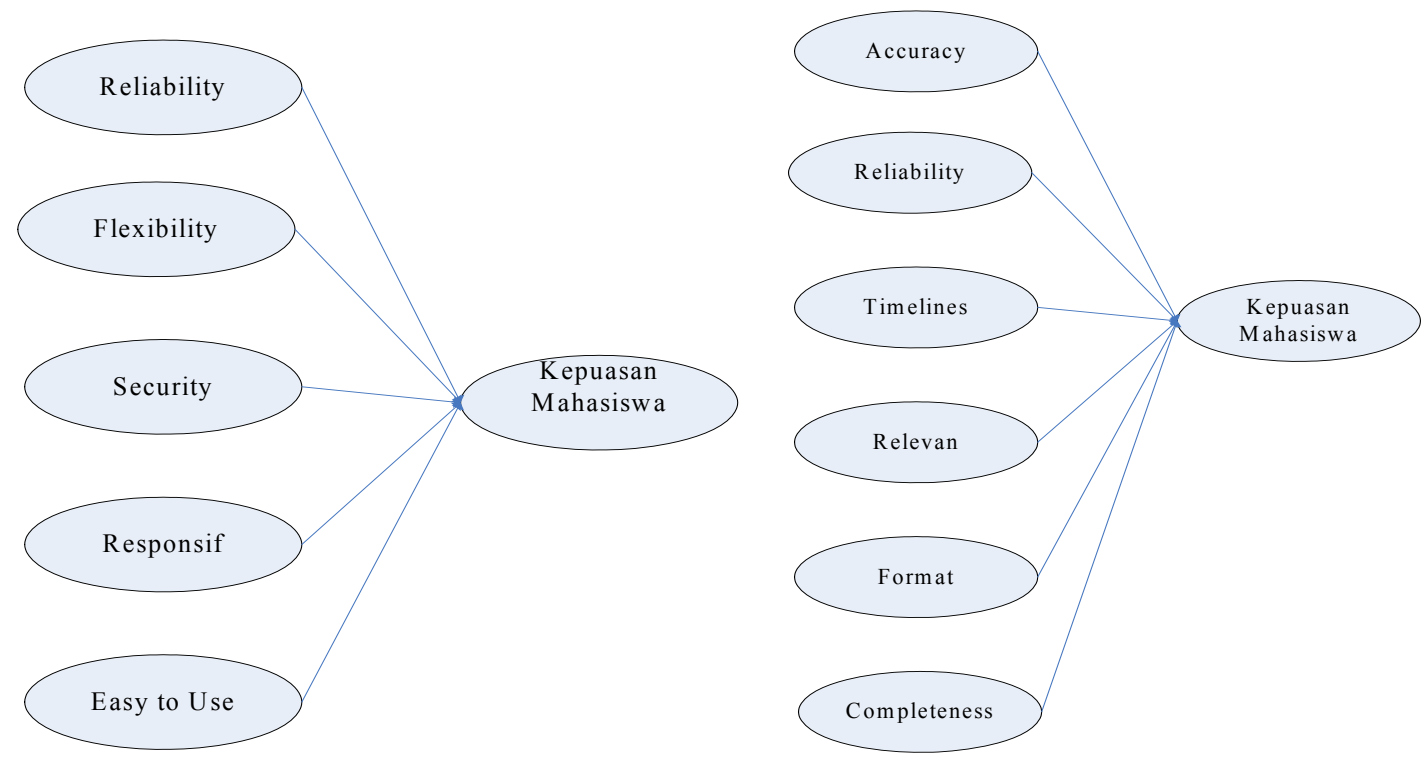

Gambar 6 Hubungan Variabel Kualitas Sistem Infromasi dan Kualitas Informasi Terhadap Kepuasan Mahasiswa dan Karyawan (Diadopsi dari Xiao \& Dasgupta, 2002) 


\section{Hasil Olah Data antara Kualitas Sistem Informasi terhadap Kepuasan Mahasiswa dan Karyawan}

Pada tabel Hasil Perhitungan Model Summary Regresi Linier Variabel Kualitas Sistem Informasi terhadap Kepuasan Pelanggan terdapat $R$ Square sebesar 0,382 dari koefisien korelasi $(0,618)$ R-Square disebut koefisien determinan yang dalam hal ini sebesar 38,2\% hasil kepuasan mahasiswa dan karyawan dapat dijelaskan oleh variabel Kualitas Sistem Informasi (X) sedangkan sisanya di jelaskan variabel lain yang berarti kualitas sistem informasi berpengaruh terhadap kepuasan Mahasiswa dan karyawan $\left(\mathrm{H}_{1}\right)$.

Pada tabel uji Anova variabel kualitas sistem informasi terhadap kepuasan pelanggan terdapat bahwa nilai probabilitas atau sig $=0,000<0,05$. Hal ini menunjukkan bahwa model Linier dapat digunakan. Uji Koefisien variabel kualitas sistem informasi terhadap kepuasan pelanggan digunakan untuk mengetahui pengaruh variabel bebas secara individu terhadap variabel terikat. Jika nilai signifikan lebih kecil dari $0,05(\mathrm{a}<0,05), \mathrm{H}_{0}$ ditolak dan $\mathrm{H}_{1}$ diterima. Tabel ini menunjukkan regresi yang dicari. Nilai sig yang di atas adalah 0,000 dan $0,000(<0,05)$. Dengan demikian dapat disimpulkan bahwa nilai koefisien korelasi adalah signifikan, artinya persamaan yang tepat untuk kedua variabel ini:

$$
Y=2,95+0,404 X
$$

di mana

$\mathrm{Y}=$ Kepuasan Mahasiswa dan karyawan

$\mathrm{X}=$ Kualitas Sistem Informasi

Tabel 3 Uji a Variabel Kualiatas Sistem Informasi terhadap Kepausan Mahasiswa dan Karyawan

\begin{tabular}{cccc}
\hline Variable $(\boldsymbol{X})$ & $\boldsymbol{R}$ Square & Koefisien Korelasi & Koefisien determinasi \\
\hline Reliability & 0,703 & 0,839 & $70,3 \%$ \\
Flexibility & $\mathbf{0 . 9 3 6}$ & $\mathbf{0 . 9 6 8}$ & $\mathbf{9 3 \%}$ \\
Security & $\mathbf{0 . 8 1 2}$ & $\mathbf{0 . 9 0 1}$ & $\mathbf{8 1 . 2 \%}$ \\
Responsif & $\mathbf{0 . 9 8 1}$ & $\mathbf{0 . 9 9 1}$ & $\mathbf{9 8 . 1 \%}$ \\
Easy to Use & $\mathbf{0 . 7 8 6}$ & $\mathbf{0 . 8 8 7}$ & $\mathbf{7 8 . 6 \%}$ \\
\hline
\end{tabular}

\section{Hipotesis:}

$\mathrm{H}_{0} \quad$ : Tidak ada pengaruh positif antara variabel Kualitas Sistem Informasi dengan variable kepuasan Mahasiswa dan karyawan

$\mathrm{H}_{1} \quad$ : Ada pengaruh positif antara variabel Kualitas Sistem Informasi dengan variabel kepuasan Mahasiswa dan karyawan

Berdasarkan data, terdapat koefisien determinansi yang merupakan persentase kepuasan mahasiswa dan karyawan yang berarti variabel kualitas sistem informasi berpengaruh terhadap kepuasan mahasiswa dan karyawan $\left(\mathrm{H}_{1}\right)$. Sisanya dipengaruhi oleh variabel lain yang tidak diamati dalam penelitian ini. 


\section{Hasil Olah Data antara Kualitas Informasi terhadap Kepuasan Mahasiswa dan Karyawan}

Pengujian dengan menggunakan analisis regresi linier dengan kualitas Informasi (X2) sebagai variabel bebas terhadap kepuasan mahasiswa dan karyawan $(\mathrm{Y})$ sebagai variabel terikat. Hipotesis untuk kualitas informasi adalah sebagai berikut:

$\mathrm{H}_{0} \quad$ : Tidak ada pengaruh positif antara keenam variabel kualitas informasi terhadap variable kepuasan Mahasiswa dan karyawan

$\mathrm{H}_{1} \quad$ : Ada pengaruh positif antara keenam variabel kualitas informasi terhadap variabel kepuasan Mahasiswa dan karyawan

Pada tabel hasil perhitungan model summary regresi linier kualitas informasi terhadap kepuasan pelanggan terdapat $R$ Square sebesar 0,481 dari koefisien korelasi $(0,694)$. R-Square disebut koefisien determinansi yang dalam hal ini sebesar $48,1 \%$ hasil kepuasan mahasiswa dan karyawan dapat dijelaskan oleh variabel Kualitas Informasi (X) sedangkan sisanya dijelaskan variabel lain. Artinya kualitas informasi berpengaruh terhadap kepuasan Mahasiswa dan karyawan $\left(\mathrm{H}_{1}\right)$. Pada tabel uji Anova kualitas informasi terhadap kepuasan pelanggan terdapat bahwa nilai probabilitasnya atau $\operatorname{sig}=0,000<0,05$. Hal ini menunjukkan bahwa model Linier dapat digunakan.

Uji Koefisien digunakan untuk mengetahui pengaruh variabel bebas secara individu terhadap variabel terikat. Jika nilai signifikan lebih kecil dari $0,05(\mathrm{a}<0,05), \mathrm{H}_{0}$ ditolak dan $\mathrm{H}_{1}$ diterima. Tabel ini menunjukkan regresi yang dicari. Nilai sig yang di atas adalah 0,000 dan 0,000 $(<0,05)$, dengan demikian dapat disimpulkan bahwa nilai koefisien korelasi adalah signifikan artinya persamaan yang tepat untuk kedua varibael ini adalah :

$$
Y=2,391+0,476 X
$$

di mana

$\mathrm{Y}=$ Kepuasan Mahasiswa dan Karyawan

$\mathrm{X}=$ Kualitas Informasi

Tabel 4 Uji Variabel Kualiatas Informasi terhadap Kepausan Mahasiswa dan Karyawan

\begin{tabular}{lccc}
\hline \multicolumn{1}{c}{ Varaibel $(\boldsymbol{X})$} & $\boldsymbol{R}$ Square & Kefisien Korelasi & Koefisien determinasi \\
\hline Accuracy & 0,796 & 0,892 & $79,6 \%$ \\
Reliability & $\mathbf{0 . 7 8 9}$ & $\mathbf{0 . 8 8 8}$ & $\mathbf{7 8 . 9 \%}$ \\
Format & $\mathbf{0 . 7 8 6}$ & $\mathbf{0 . 8 8 7}$ & $\mathbf{7 8 . 6 \%}$ \\
Completeness & $\mathbf{0 . 8 6 5}$ & $\mathbf{0 . 9 3 0}$ & $\mathbf{8 6 . 5 \%}$ \\
\hline
\end{tabular}

\section{Hipotesis:}

$\mathrm{H}_{0} \quad$ : Tidak ada pengaruh positif antara variabel Kualitas Informasi dengan variabel kepuasan Mahasiswa dan karyawan

$\mathrm{H}_{1} \quad$ : Ada pengaruh positif antara variabel Kualitas Informasi dengan variabel kepuasan Mahasiswa dan karyawan

Berdasarkan data, terdapat koefisien determinansi yang merupakan persentase kepuasan mahasiswa dan karyawan yang berarti variabel kualitas informasi berpengaruh terhadap kepuasan mahasiswa dan karyawan $\left(\mathrm{H}_{1}\right)$, sedangkan sisanya dipengaruhi oleh varibal lain yang tidak diamati dalam penelitian ini. 


\section{Hasil Olah Data antara Kualitas Sistem Informasi dan Kualitas Informasi terhadap Kepuasan Mahasiswa dan Karyawan}

Pengujian dengan menggunakan analisis regresi linier berganda dengan kualitas sistem informasi (X1) dan kualitas informasi (X2) sebagai variabel bebas terhadap kepuasan mahasiswa dan karyawan (Y) sebagai variabel terikat. Pada Tabel hasil perhitungan model korelasi kualitas sistem informasi dan kualitas informasi terdapat korelasi antara X1 terhadap X2 dan sebaliknya adalah sebesar 0.989 karena nilai korelasi tersebut di atas $0,5(0.989>0.5)$ atau nilai korelasi mendekati 1 . Artinya, variabel X1 dan Variabel X2 memiliki hubungan atau korelasi.

Dari hasil uji Anova didapatkan tingkat signifikan sebesar 0.000. Karena probabilitas ini kurang dari $0,05, \mathrm{H}_{0}$ ditolak sehingga dapat disimpulkan bahwa ada pengaruh antara kualitas sistem informasi dan kualitas informasi terhadap kepuasan mahasiswa dan karyawan. Pada Tabel ini terdapat bahwa nilai probabilitasnya atau sig $=0,000<0,05$ hal ini menunjukan bahwa model Linier dapat digunakan.

Uji koefisien digunakan untuk mengetahui pengaruh variabel bebas secara individu terhadap variabel terikat. Jika nilai signifikan lebih kecil dari $0,05(\mathrm{a}<0,05), \mathrm{H}_{0}$ ditolak dan $\mathrm{H}_{1}$ diterima.

$$
Y=2,068+1.941 X 1+2.492 X 2
$$

di mana

$$
\begin{aligned}
& \mathrm{Y}=\text { Kepuasan Mahasiswa dan karyawan } \\
& \mathrm{X} 1=\text { Kualitas Sistem Informasi } \\
& \mathrm{X} 2=\text { Kualitas Informasi }
\end{aligned}
$$

Berdasarkan hasil pengujian statistik diketahui bahwa terdapat hubungan yang signifikan antara kualitas sistem informasi dan kualitas informasi dari sistem informasi GF Services dengan kepuasan mahasiswa dan karyawan hal tersebut dapat diketahui dari penjelasan berikut. Analisis kualitas sistem informasi dan kualitas informasi dari sistem informasi GF Services terhadap kepuasan mahasiswa dan karyawan diketahui memiliki nilai $38.2 \%$ dan $48.1 \%$. Artinya ada pengaruh positif antara kualitas sistem informasi dan kualitas informasi dari sistem informasi GF Services terhadap kepuasan mahasiswa dan karyawan sebesar nilai tersebut di atas. Sementara sisanya dijelaskan oleh variabel-variabel lain yang tidak dijelaskan dalam penelitian ini.

\section{SIMPULAN}

Berdasarkan hasil dan analisis data sebelumnya dapat disimpulkan sebagai berikut. Pertama, hasil pengukuran maturity level dengan menggunakan kerangka kerja COBIT pada pemanfaatan Sistem Informasi pada GF Services berada pada posisi 2.951 atau mendekati dari standar yang ditetapkan secara International yaitu 3.00. Artinya, proses proses telah didokumentasikan dan dikomunikasikan dengan baik. Kedua, tanggapan mahasiswa dan karyawan terhadap kualiatas sistem informasi dan kualitas informasi adalah positif. Artinya, meningkatnya kualitas informasi dan kualitas sistem informasi GF Services akan meningkatkan kepuasan mahasiswa dan karyawan. Ketiga, hasil analisis regresi dan korelasi antara faktor kualitas sistem informasi dan kualitas informasi terhadap kepuasan mahasiswa dan karyawan sebesar $38.2 \%$ dan $48.1 \%$, sementara selebihnya dipengaruhi oleh factor-faktor lain; yang artinya, factor-faktor tersebut berpengaruh terhadap kepuasan mahasiswa dan karyawan. Keempat, usaha dalam mencapai target yang telah ditetapkan, yaitu dengan mempertahankan meningkatkan dan memperbaiki proses-proses yang saat masih berada pada tingkat maturity level 2 atau Repeatable but Intuitive ke tingkat 4 atau Managed and Measureable. 
Saran yang dapat diberikan dalam penelitian ini adalah sebagai berikut. Pertama, perbaikan dapat dilakukan melalui penelusuran hasil pengukuran maturity level yang menunjukkan proses-proses yang masih berada di bawah harapan/target yang ingin dicapai. Kedua, evaluasi secara periodik perlu dilakukan terhadap pemanfaatan Teknologi Informasi minimal 2 tahun sekali untuk dapat mengantisipasi perubahan pada proses bisnis, sehingga fungsi teknologi informasi dapat lebih dirasakan manfaatnya oleh pengguna.

\section{DAFTAR PUSTAKA}

Abu-Musa, A. A. (2009). Exploring COBIT process for ITG in Saudi Organization. The International Journal of Digital Accounting Research, 9, 99-126.

DeLone, W. H., \& McLean, E. R. (2003). The DeLone and McLean model of Information Systems success: A ten-year update. Journal of Management Information Systems, 19(4), 9-30.

Fitrianah, D., \& Sucahyo, Y. G. (2010). Audit Sistem Informasi/Teknologi Informasi dengan kerangka kerja COBIT untuk evaluasi manajemen teknologi informasi di Universitas XYZ. Jurnal Sistem Informasi MTI-UI, 4(1), 37-46.

Gondodiyoto, S. (2007). Audit Sistem Informasi Pendekatan COBIT. Jakarta: MitraWacana Media.

Hudiarto., \& So., I. G. (2010). Menggunakan kerangka kerja COBIT pada domain Deliver and Support (Studi Kasus pada PT. Carrefour Indonesia, Jakarta). Seminar Nasional Aplikasi Teknologi dan Informasi (SNATI) (pp. 121-126). Yogyakarta, 19 Juni 2010.

Ilias, A., \& Suki, N. B. M. (2008). The End-user Computing Satisfaction (EUCS) on Computerized Accounting Sistem (CAS): How they perceived? Journal of Internet Banking and Commerce, 13(1), 1-18.

IT Governance Institut. (2007). COBIT 4.1 Control Objectives, Management Guidelines, Maturity Model. USA.

Lubis, R. M., \& Arma, A. J. A. (2003). Teknik sampling dalam pelaksanaan penelitian. Info Kesehatan, 7(1), 59-67.

Nugroho, B. A. (2005). Strategi Jitu Memilih Metode Statistik Penelitian dengan SPSS. Yogyakarta: Andi.

Nurhayati. (2008). Studi perbandingan metode sampling antara simple random dengan stratified random. Jurnal Basis Data, 3(1), 18-32.

Silitonga, T. P., \& Ali, A. H. N. (2010). Sistem manajemen insiden pada program manajemen help desk dan dukungan TI berdasarkan Framework ITIL V3. Seminar Nasional Informatika (pp. 210-218). Yogyakarta: UPN Veteran.

Triyanto, A., \& Santosa, T. E. C. (2009). Organizational Citizenship Behavior (OCB) dan pengaruhnya terhadap keinginan keluar dan kepuasan kerja karyawan. Jurnal Manajemen, $7(4), 1-13$. 
Tuttle, B., \& Vandervelde, S. D. (2007). An empirical examination of COBIT as an internal control framework for information technology. International journal of Accounting Information Sistems, 8, 240-263.

Xiao, L., \& Dasgupta, S. (2002). Measurement of user satisfaction with web-based information sistems: an empirical study. In AMCIS Proceedings (pp. 1149 - 1155). Available http://aisel.saisnet.org/amcis2002/159 